\title{
Egzoz Atık Isısından Termoelektrik Modülle Enerji Üreten Sistem Tasarımı ve Optimizasyonu
}

\author{
${ }^{1}$ Murat KARABEKTAŞ ve ${ }^{* 2}$ Gülden BOLATLI \\ ${ }^{1}$ Teknoloji Fakültesi Makine Mühendisliği Bölümü, Sakarya Üniversitesi, Sakarya, Türkiye \\ ${ }^{2}$ Teknoloji Fakültesi Otomotiv Mühendisliği Bölümü, Sakarya Üniversitesi, Sakarya, Türkiye
}

\section{ÖZET}

Günümüzde enerji ihtiyacının artmasıyla birlikte bu ihtiyacın büyük bir bölümünü karşılayan fosil yakıtların tüketimi de artmaktadır. Yanması sonucunda karbon dioksit $\left(\mathrm{CO}_{2}\right)$ gibi zararlı gazlar açığa çıaran fosil yakıtlar küresel ısınma sorunu gibi çevreye ciddi zararlar vermektedir. Fosil yakıt tüketimin çevreye verdiği zararları önlemek amacıyla son yıllarda sürdürülebilir enerji üzerine yapılan çalışmalar da artmıştır. Atık ısının geri kazanımı da bu çalışmalarda önemli bir yere sahiptir. Bu çalı̧̧mada; bir aracın egzozundan atmosfere verilen atık ısıdan termoelektrik jeneratörle (TEJ) elektrik enerjisi üreten sistem tasarımı yapılmıştır. Termoelektrik modüllerin (TEM) sıcak yüzeyine isı transfer edebilmek için tasarlanan 1sı eşanjörünün gövdesinde bulunan kanatçık yapıları değiş̧tirilerek 1sı transferinin en iyi olması için sistem optimize edilmiştir. Tasarımda 12, 14, 16 ve 18 kanatçıklı olmak üzere 4 çeşit yapı ANSYS Fluent modülünde analiz edilmiş ve eşanjörün TEM'le temas eden yüzeylerinde 1 sıl dağılım grafikleri değerlendirilmiştir. Bu sonuçlara göre; ortalama değerlerde isıl dağılım gösteren yapı maksimum $226^{\circ} \mathrm{C}$ yüzey sıcaklığı ile içten yanmalı motor performansını daha fazla kanatçıklı yapılara göre daha az etkilemesi ve kolay imal edilebilir olmasından dolayı 14 kanatçıklı yapıya sahip eşanjör tasarımı olduğu kanısına varılmıştır. Daha sonra tasarlanan 14 kanatçıklı eşanjör imal edilerek diğer ekipmanlarla birlikte TEM'den elektrik üreten düzenek hazırlanmıştır.

Anahtar kelimeler: TEM, TEJ, atık 1s1, sürdürülebilir enerji.

\begin{abstract}
Nowadays, with the increase in energy demand, the consumption of fossil fuels that meet a large part of this demand is also increasing. Fossil fuels which release harmful gases such as carbon dioxide as a result of combustion, cause serious damage to the environment, such as the problem of global warming. In recent years, studies about sustainable energy have also increased in order to prevent to environmental damages caused by fossil fuel consumption. Recovery of waste heat also has an important place in these studies. In this study; the design of a system that produces electrical energy with a thermoelectric generator (TEG) from waste heat is given to the atmosphere from an exhaust of a vehicle has been made. The system has been optimized to be the best of the heat transfer by changing the fin structures in the body of the heat exchanger designed to transfer heat to the hot surface of the thermoelectric modules (TEM). In design,four types of structures 12, 14, 16 and 18 finned have been analyzed in the ANSYS Fluent modüle and thermal distribution graphs on the surfaces which contacted with TEM of the exchanger have been evaluated. According to these results; it has been concluded that the structure which has a thermal distribution at the average values is 14 finned heat exchanger design due to the fact that it has max $226{ }^{\circ} \mathrm{C}$ and internal combustion engine is less affected then the more finned structures and it easily manufactured. After that, by manufacturing 14 finned heat exchangers designed, the equipment producing electricity from TEM has been prepared together with other equipments.
\end{abstract}

Key words: TEM, TEG, waste heat, sustainable energy.

*Corresponding author: Address: Faculty of Technology, Department of Automotive Engineering Sakarya University, 54187, Sakarya TURKEY. 


\section{GİRIŞ̧}

İnsanlığın gelişmesindeki en önemli etkenlerden biri olan enerjinin kullanımı, dünyada nüfus artı̧̧ı, ekonomik gelişmeler, sanayileşme ile birlikte kalkınma ve refahın artmasıyla önemli oranda artış göstermektedir. Dünyada 2006 yılında tüketilen toplam enerji 11266,7 milyon ton eşdeğer petrol (mtep) iken, 2016 yllında toplamda 13276,3 mtep enerji tüketilmişsir. Bu verilere göre dünyada tüketilen toplam enerji miktarı 10 yılda $\% 15$ artış göstermiştir. Tüketimi her geçen gün artan bu enerjinin $\% 85,5^{\prime}$ ini fosil yakıtlar oluştururken diğer $\% 14,5^{\prime}$ lik bölümünü nükleer enerji, hidroelektrik ve yenilenebilir enerjiler oluşturmaktadır. [1]

Dünya atmosferine insanların enerji kullanımı, sanayi ve tarım gibi çeşitli faaliyetleri sonucunda en fazla gönderilen ve sera gazı olarak bilinen $\mathrm{CO}_{2}$ dünyaya gelen güneş ışıllarının bir kısmını tutarak yeryüzünün 1s1 kaybına engel olmaktadır. Bu gazın miktarının artması küresel 1sınma olarak bilinen atmosferdeki isının artmasına sebep olmaktadır. Atmosferdeki bu sıcaklık artışı buzulların erimesine, tatlı suların buharlaşarak kuraklık oluşumuna dolayısıyla canlıların yaşaması için uygun iklim koşullarına engel olmaktadır [2,3].

Özellikle enerji ihtiyacının artışına bağlı olarak çevreye olan zararlı etkileriyle fosil yakıt tüketiminin sürekli artması ve var olan kısıtlı kaynak rezervlerinin giderek azalması dünya enerji politikasını yeniden gözden geçirmeye, sürdürülebilirlik ve enerjiyi etkin kullanmaya yöneltmiştir. $\mathrm{Bu}$ bağlamda kalkınma ile enerji kullanımının devamlılı̆̆ını sağlamak ve sürdürülemez duruma düşmemesi için önlemler alınmasını gerektiren sürdürülebilir kalkınma önem kazanmıştır. Sürdürülebilir kalkınmayı sağlamak, enerji kaynaklarının tükenmemesini ve bunların kullanımında meydana gelebilecek olumsuz çevre etkilerinin göz ardı edilmemesini kapsamaktadır. Buna göre sürdürülebilirlik için enerji kaynakları temiz ve tükenmez olmalıdır. Sürdürülebilirliği sağlayan temiz ve tükenmez olan enerji kaynakları günlük güneş enerjisi ve biokütle, rüzgâr, deniz dalgaları, okyanuslardaki sıcaklık farkları, yağış (su gücü) gibi güneş enerjisi türevleri, yer içi 1sısı ve gelgitlerden oluşmaktadır. Sürdürülebilirliği sağlayan ve yenilenebilir enerji kaynakları olarak nitelendirilen bu enerji kaynaklarından enerji elde etmek üzerine ülkemizde ve dünyada etkin çalışmalar yapılmaktadır. Bunun yanı sıra yapılan başka bir çalışma konusu da enerjinin geri kazanımı ve verimli kullanımı üzerinedir. Buna en iyi örneklerden biri atık ısı enerjisinin tekrar kazanımıdır [2-4].

Dünyada ve ülkemizde kullanımı giderek yaygınlaşan otomobillerin içten yanmalı motorlarında yanma sonucunda enerjinin efektif kullanımı benzinli motorlar için yaklaşı $\% 25$, dizel motorlar için yaklaşı $\% 40$ 'tır. Geriye kalan enerjinin \%2-\%10'u sürtünme ve pompalama, \%10-\%35'i soğutma, yağlama ve diğer 1sı kayıpları ile kaybolmakta ve \%20-\%40'1 egzozdan atılmaktadır. $\mathrm{Bu}$ tipik enerji dağılımından anlaşıldığı üzere yakıt enerjisinin üçte ikilik önemli bir bölümü çevreye isı olarak atılmaktadır [5].

$\mathrm{Bu}$ verilere göre egzozdan atılarak atmosfere salınan enerji oranının, otomobili hareket ettirmek için kullanılan enerjinin etkili kullanım oranından fazla olduğu görülmektedir. Dışarıya atılan böylesine önemli ve büyük orandaki enerjinin kullanımı açısından önemli bir kayıp olarak değerlendirilmektedir. Ayrıca bu oranın artması, içten yanmalı motorlarda fosil yakıtların yanması sonucu açığa çıkan ve çevre için fazlası zararlı olan $\mathrm{CO}_{2}$ gazının egzozdan atmosfere atılan oranının da arttığını göstermektedir. Egzozdan dışarıya salınan bu ısı enerjisini tekrar kazanmak günümüz teknolojisi ile mümkündür. Son yıllarda atık 1sı enerjisinin geri kazanımı 
üzerine yapılan otomobil egzoz atık 1sısından elektrik enerjisi elde etme çalışmaları önem kazanmıştır [4].

B. Orr, A. Akbarzadeh, P. Lappas, araçların yakıt tüketimini ve $\mathrm{CO}_{2}$ emisyonunu azaltmak amacıyla ısıl tüpler ve TEJ kullanarak araç motorunun atık 1sısından elektrik enerjisi elde etmişlerdir. 8 adet TEM kullanılarak yapılan deneyde maksimum güç çıkışı $37.85 \mathrm{~W}$ olarak gözlemlemişlerdir [6].

Changxin Liu, Xinxiang Pan, Xiaofeng Zheng, Yuying Yan, Weizhong. Li, araç egzozundan atık ısının enerji olarak kazanımı için TEJ prototipi geliştirmişlerdir. TEJ prototipinde toplam 96 adet TEM kullanmışlardır. Deneysel çalışmalar sonucunda modül sıcak yüzey sıcaklığı $473 \mathrm{~K}$ olduğu durumda üretilen maksimum güç çıkışını $250 \mathrm{~W}$ olarak elde etmişlerdir [7].

C.Q. Su, W.S. Wang, X. Liu, Y.D. Deng, otomobil egzoz atık 1sısından elektrik enerjisi elde eden TEJ tasarımı yapmışlardır. Tasarımda önce computational fluid dynamics (CFD) programında isı eşanjörünün iç yapısı ve malzemesini değiştirerek simüle etmişler. Daha sonra CFD simülasyon sonuçları ve deneysel sonuçlar arasındaki uyuşmaya göre $660 \mathrm{~mm}$ x $305 \mathrm{~mm}$ boyutlarında yüzey alanlı ve akordeon şekilli pirinç malzemeden yapılmış model sıcak yüzey oluşturmak için uygun olduğu kanısına varmışlardır [8].

$\mathrm{Bu}$ çalışmada araç egzozundan atılarak atmosfere verilen ısıdan TEJ'le elektrik enerjisi elde etmek amacıyla sistem tasarımı yapılmıştır. Bu amaçla TEM'lerin yüzeyine yerleştirilerek 1sı enerjisinden faydalanacakları 1sı eşanjörünün kanatçık yapıları değiştirilerek ANSY Fluent programında simüle edilmiş ve sistem optimize edilmiştir.

\section{TERMOELEKTRIKK JENERATÖRDEN ELEKTRIK ÜRETIMİ}

P-tipi ve n-tipi yarı iletken malzemelerden oluşan çok sayıda 1sıl çiftin elektriksel olarak seri ve termal olarak paralel bağlanmasıyla TEM'ler elde edilir. TEM'ler genellikle TEJ ve termoelektrik soğutucular olmak üzere 2'ye ayrılırlar. Bu cihazlar hareketsiz parçalara sahiptir ve bakım gerektirmezler. TEJ'ler elektrik santrallerinden ve otomobillerden atık 1sisının geri kazanımı için büyük bir potansiyele sahiptir. Bu jeneratörler aynı zamanda uzayda ve dağlık telekomünikasyon sitelerindeki uzak alanlarda güvenilir güç sağlarlar [9].

Seebeck etkisi, sıcaklık farkının elektriğe dönüşümü olarak tanımlanır. Sıcaklık farkında iki metal ya da yarı iletken arasında termoelektrik potansiyel farkı oluşmaktadır. Bu elektrik potansiyeline Seebeck etkisi denir [10]. TEJ'in çalışma prensibi Seebeck etkisine dayanır. Şekil 1'de bu etkiye göre TEJ'in çalışması gösterilmektedir. Isıl çiftlerin bakır iletkenlerle bağlanması ve seramik katmanlarla izole edilmesiyle oluşan TEM'in sicak yüzeyinin sıcak ortamdan isı girişi ile 1sıtılması ve soğuk yüzeyinin soğuk ortama ısı atılarak soğutulmasıyla iki yüzey arasında oluşan sıcaklık farkından dolayı elektrik üretimi gerçekleşmektedir [11,12]. 


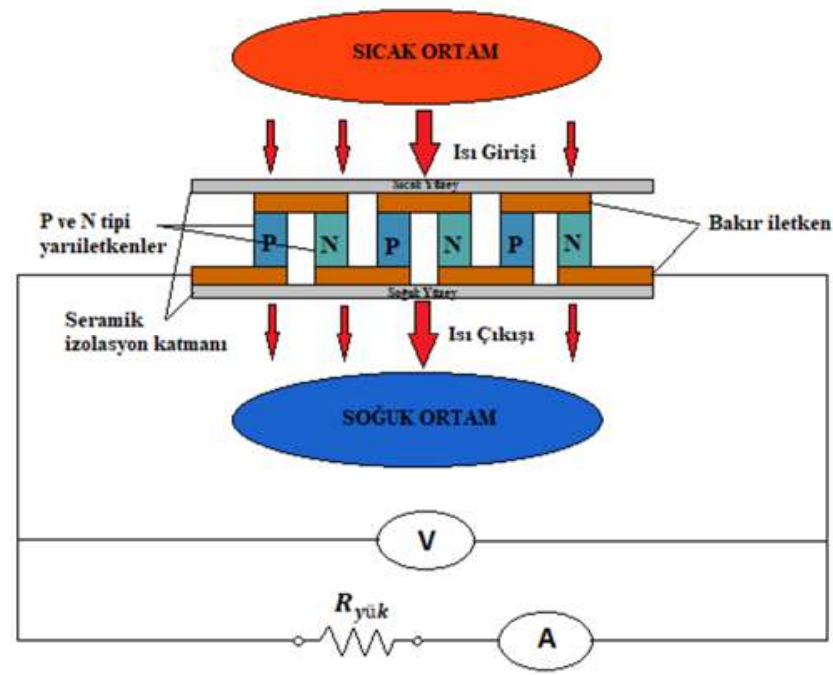

Şekil 1. TEM'in jeneratör olarak kullanılması

\section{TERMOELEKTRIKK JENERATÖR ÇALIŞMA DÜZENEĞINININ TASARIMI VE ÇALIŞMASI}

TEM'in jeneratör olarak kullanılabilmesi için modülün bir yüzeyi sıcak diğer yüzeyi soğuk olması gerekmektedir. Sıcaklık farkı arttıkça elde edilen güç artmaktadır. Bu amaçla çalışma düzeneğinin temel elemanını 1S1 eşanjörü oluşturmaktadır. Isı eşanjörü bir aracın egzozundan atılan atık ısıyı TEM'lerin yüzeyine en iyi şekilde iletme görevine sahiptir.

Şekil 2'de tasarlanan TEJ deney düzeneğinin çalışma diyagramı gösterilmektedir. Araç egzozu 1S1 eşanjörüne bağlanmıştır, atık gaz eşanjöre 1S1 enerjisinin bir kısmını transfer ederek eşanjörün diğer ucundan atılmaktadır. Üzerine 1sı enerjisini alan 1sı eşanjörü bu 1sıyı yüzeyine monte edilmiş TEM'lerin sıcak yüzeyine iletilmektedir ve enerji üretilmesi için en önemli katkıyı sisteme sağlar. Bu sistemde TEM'ler ısı eşanjörünün en geniş iki yüzeyine monte edilmektedir.

Is1 eşanjöründen egzoz gazı geçirilirken TEM'in sıcak yüzeyine iletilen 1sı bir süre sonra soğuk yüzeyin de isınmasına sebep olmaktadır. TEM'in sıcak ve soğuk yüzeyi arasındaki sıcaklık farkını arttırmak amacıyla ısınan soğuk yüzeyi soğutmak için eşanjörün her iki yüzeyinde de soğutma ünitesi TEM'lerin soğuk yüzeyine temas edecek şekilde yerleştirilmektedir. Bir su deposundan su pompası yardımıyla bu soğutma üniteleri içerisine soğuk su gönderilmektedir. Soğuk su pompalamayla hazne içerisinden sürekli soğuk su geçirilerek isınan su devirdaim yapmakta ve böylece TEM'in soğuk yüzeyi soğuk tutulmaktadır. Soğutucu hazneden gelen 1sınmış su radyatör yardımıyla soğutularak su deposuna gönderilmektedir. Ayrıca soğutucu haznelere giren ve hazneden çıkan suyun sıcaklıklarını termokupllarla ve egzoz gazının eşanjöre giriş-çıkış sıcaklıkları Pt100 tipi termokupl ile ölçülecek şekilde deney düzeneği tasarımı yapılmıştır. 


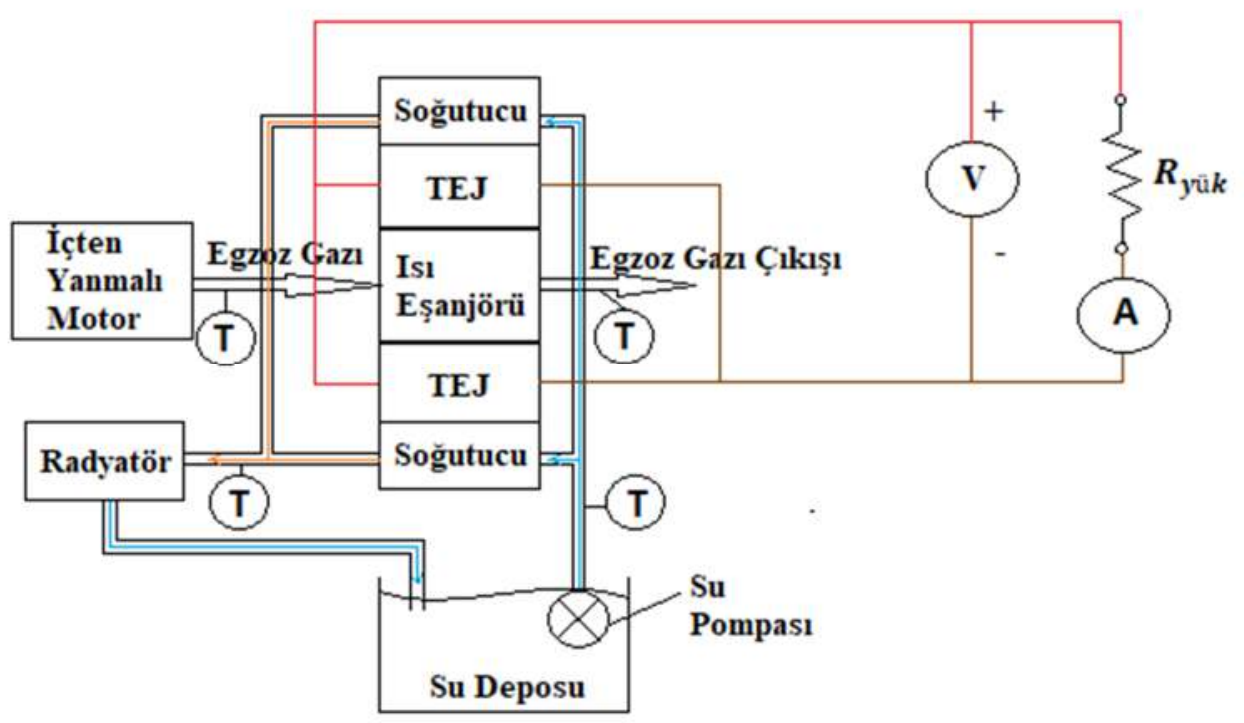

Şekil 2. TEJ deney düzeneği çalışma diyagramı

\section{ISI EŞANJÖRÜ TERMAL ANALIZII VE OPTIMIZASYON ÇALIŞMALARI}

Bir TEJ den en iyi performansın alınması için TEM'in sıcak yüzeyine iletilen 1sı enerjisinin TEM kapasitesi dahilinde maksimum olması önemlidir. $\mathrm{Bu}$ noktada TEM'in sıcak yüzeyine iletilebilecek maksimum 1S1 enerjisinin sağlanması için 1S1 eşanjörünün iç yapısının tasarımına odaklanmak doğrudur. Bu bölümde 1sı eşanjörünün iç yapısını oluşturan kanatçıların tasarımı ele alınmaktadır.

Bu çalışmada eşanjör tasarımından beklenen özellik; egzozdan aldığ 1s1 enerjisini en iyi şekilde yüzeyine iletmesi ve egzoz gazını aracın içten yanmalı motorun çalışmasını ve performansını etkilememesi için dış ortama rahatlıkla atılmasını sağlamasıdır. Ayrıca TEM'ler eşanjör yüzeylerinin orta bölgelerine yerleştirileceği için en iyi ısı dağılımının bu bölgelerde toplanması da beklenmektedir.

Tasarlanan 1S1 eşanjörünün egzoz gazı giriş çıkışını gösteren genel görünümü Şekil 3’te belirtilmektedir.

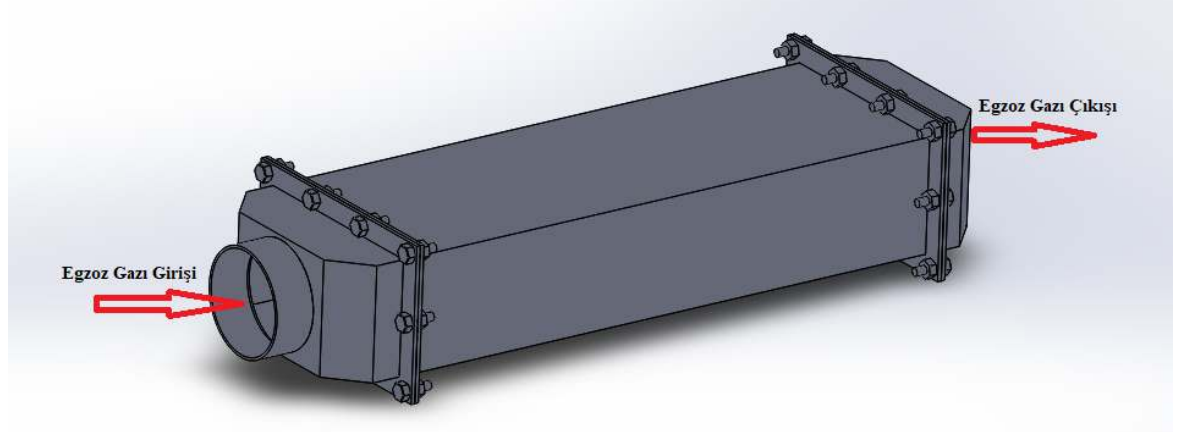




\section{Şekil 3. Is1 eşanjörü genel görünümü}

Isı transfer denklemlerine göre bir malzemenin 1sıyı iletmesi malzemenin 1sı iletkenlik katsayısı ve yüzey alanı ile doğru orantılıdır [13]. Bu yöntemle eşanjör sisteminin ısı iletkenliğini arttırmak amacıyla eşanjör gövdesi kanatçıklı yapıda tasarlanmıştır. En iyi tasarımı elde etmek amacıyla oluşturulan tasarımda kanatçık sayıları değiştirilerek kıyaslamalar yapılmıştır.

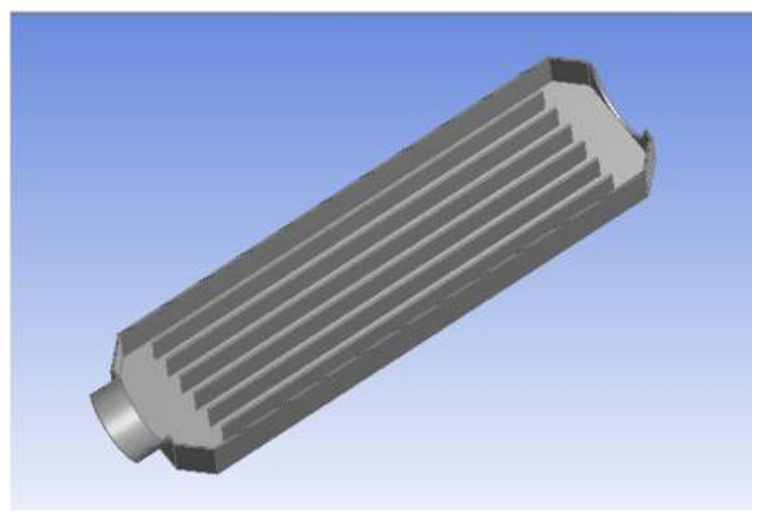

a)

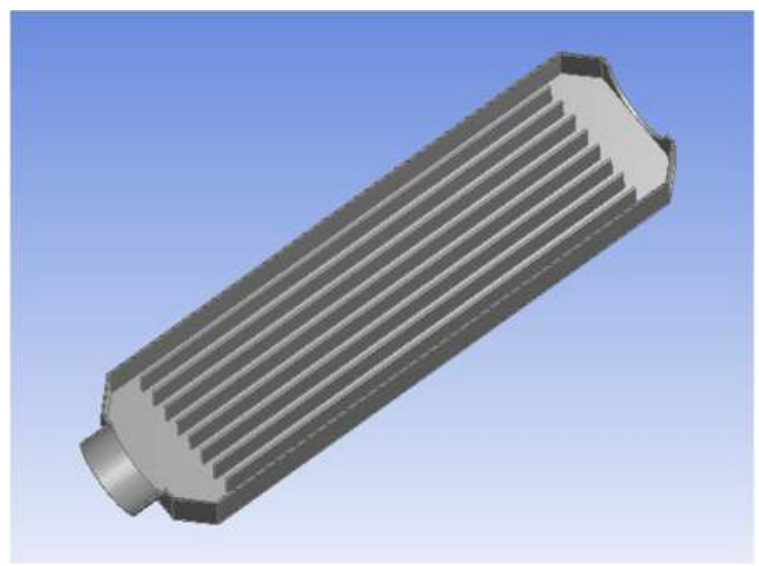

c)

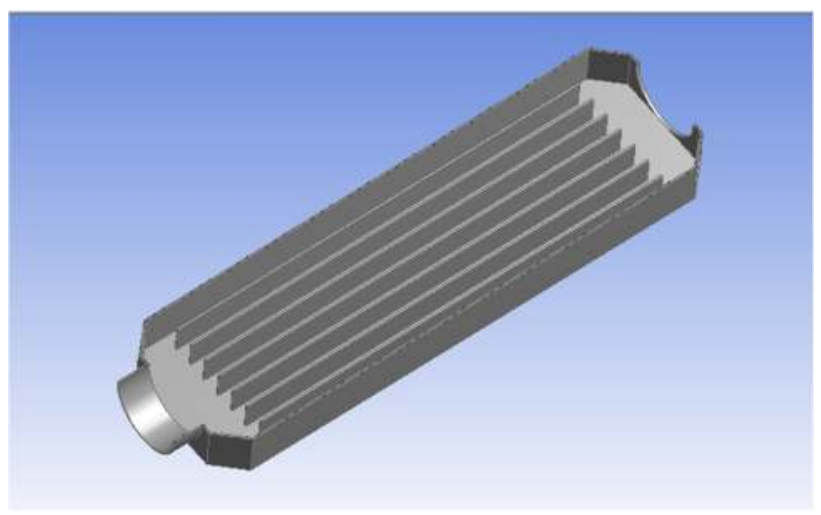

b)

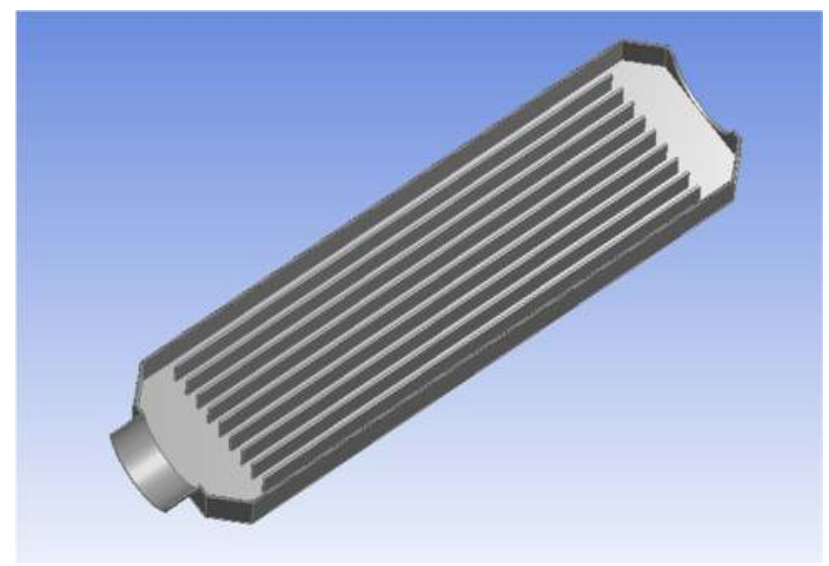

d)

Şekil 4. a) 12 kanatçıklı, b) 14 kanatçıklı, c) 16 kanatçıklı, d) 18 kanatçıklı eşanjör sistemi kesit görünümleri

Şekil 4'te sırasıyla 12, 14, 16 ve 18 kanatçığa sahip eşanjör gövdelerinin kesit görünümleri verilmektedir. İlk görünümdeki yap1 6 alt ve 6 üstte olmak üzere 12, ikinci görünümdeki yap1 7 alt ve 7 üstte olmak üzere 14, üçüncü görünümdeki yapı 8 alt ve 8 üst olmak üzere 16 ve dördüncü görünümdeki yap1 9 alt ve 9 üst olmak üzere 18 kanatçığa sahiptirler.

Tasarımı oluşturulan bu kanatçıklı eşanjör yapılarının ANSYS Fluent programında analizleri yapılarak 1sıl dă̆ılımlar incelenmiştir. TEM'lerin sıcak yüzeylerine temas edecek olan alan is1 eşanjörünün en geniş alana sahip dış yüzeyleri olduğu için 1sı eşanjörünün bu yüzeylerindeki analiz sonuçları gözlemlenmiştir. Şekil 5 'te ANSYS Fluent de akış analizi yapılan sırasıyla 12, 14, 16 ve 18 kanatçıklı yapıya sahip eşanjörlerin yüzeyindeki ısıl dağılımlar verilmektedir. 


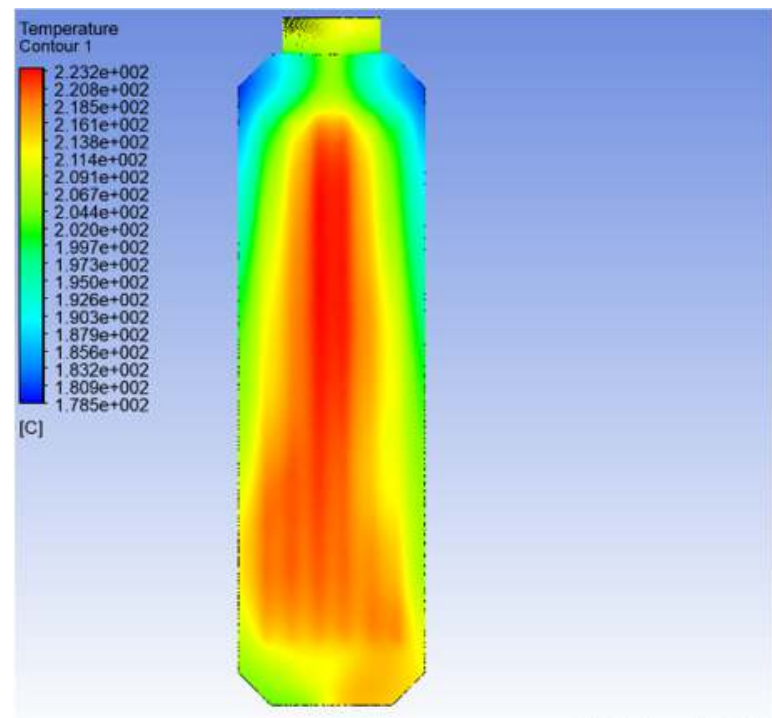

a)

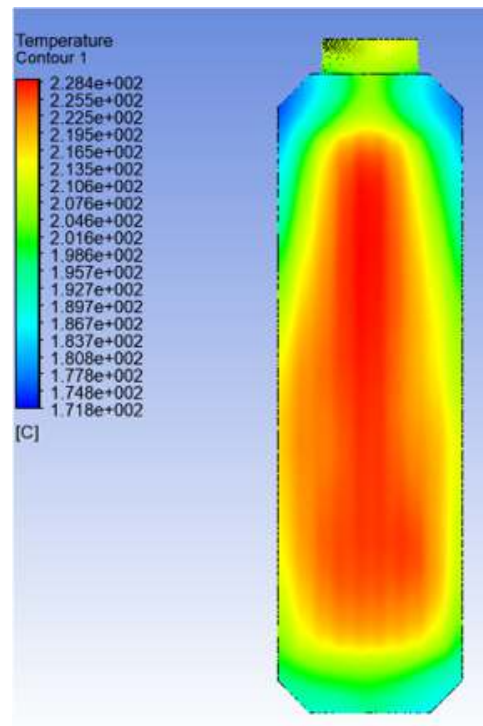

c)

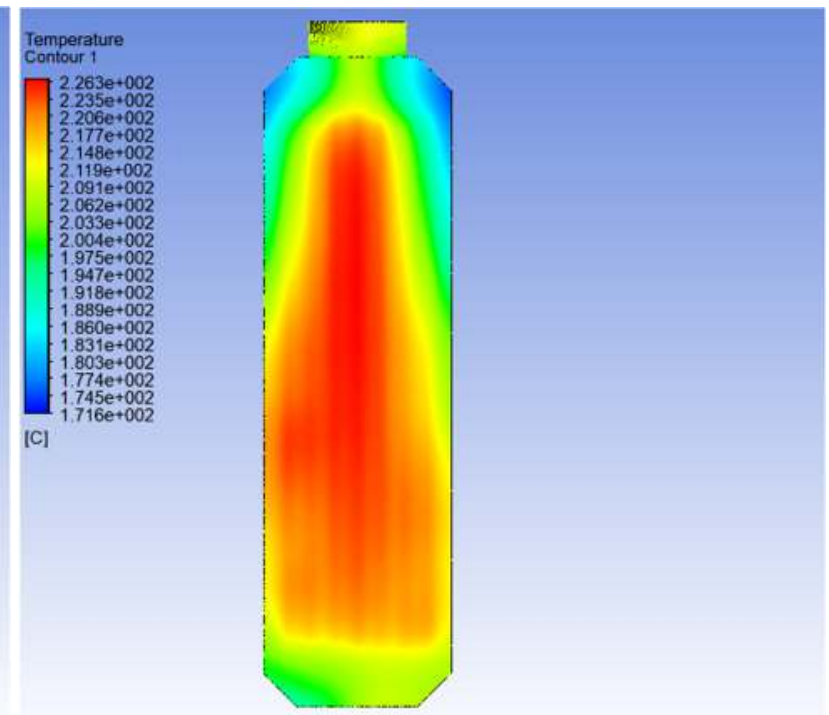

b)

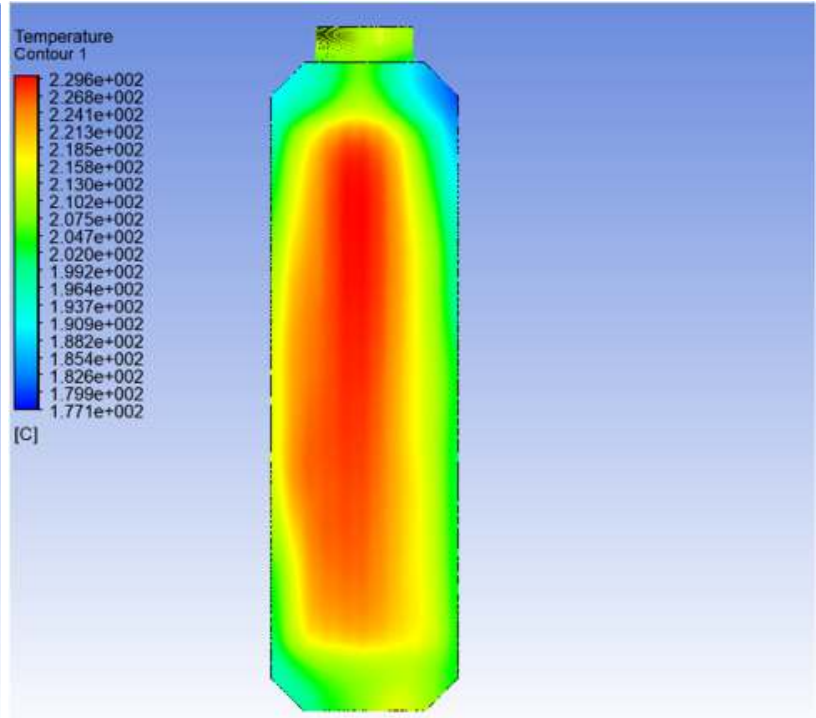

d)

Şekil 5. a) 12 kanatçıklı, b) 14 kanatçıklı, c) 16 kanatçıklı ve d) 18 kanatçıklı yapıya sahip eşanjörlerin ANSYS Fluent de akış analizine göre yüzeydeki ısıl dağılım grafiği

$\mathrm{Bu}$ analizin sınır şartları belirlenirken egzoz gazının giriş sıcaklığ 1 ortalama bir değer olarak 250 ${ }^{\circ} \mathrm{C}$ kabul edilmiştir. Sonuçlara göre, 6 alt ve 6 üst 12 kanatçıklı gövdenin maksimum - minimum yüzey sıcaklığ $1223-178{ }^{\circ} \mathrm{C}$ arasında ve en yüksek yüzey sıcaklığı dağılımının gövdenin orta bölümlerde dağıldığı gözlemlenmektedir. 7 alt ve 7 üst 14 kanatçıklı gövdenin maksimum minimum yüzey sıcaklığı $226-171{ }^{\circ} \mathrm{C}$ arasında ve en yüksek yüzey sıcaklığı dağılımının gövdenin orta bölümlerde dağıldığı gözlemlenmektedir. 8 alt ve 8 üst 16 kanatçıklı gövdenin maksimum - minimum yüzey sıcaklığı $228-171{ }^{\circ} \mathrm{C}$ arasında ve en yüksek yüzey sicaklığ dağılımının gövdenin orta bölümlerde dağıldığı gözlemlenmektedir. 9 alt ve 9 üst 18 kanatçıklı gövdenin maksimum - minimum yüzey sıcaklığı $229-177{ }^{\circ} \mathrm{C}$ arasında ve en yüksek yüzey sıcaklığı dağılımının gövdenin orta bölümlerde dağıldığı gözlemlenmiştir. 
Bu sıcaklık grafikleri kıyaslandığında en yüksek sıcaklığa sahip yapı 18 kanatçıklı ve en düşük sıcaklığa sahip yapı 12 kanatçıklı gövdedir. Kanatçık sayısı arttıkça gövde yüzeyinde maksimum sıcaklığın da arttığı görülmektedir. Ancak optimize yapı seçilirken dikkat edilmesi gereken tek özellik maksimum yüzey sıcaklığı değildir. Bu çalışmada içten yanmalı motorun egzozundan atılan atık 1sı eşanjörden geçecektir. İçten yanmalı motorun çalışmasını ve performansını etkilememek de göz önünde bulundurulmalıdır. Motor yanma sonucu atılan atık 1sıyı ne kadar rahat atarsa motor o kadar etkin çalışmaktadır. Bu durumda kanatçık sayısını fazla arttırmak motor performansını olumsuz etkileyecektir. Ayrıca ürünün kolay imal edilir olması da önemlidir. Kanatçık sayısını fazla arttırmak imalatı zorlaştırmakta ve imal edilen ürünün tasarlanan yapıya göre doğruluğunu olumsuz etkilemektedir.

Eşanjör yüzeyindeki maksimum sıcaklık dağılımlarının çok büyük sıcaklık farklarına sahip olmadıkları için motor performansına engel olmamak ve imal edilebilirliğinin kolay olması göz önüne alındığında, ortalama değerde bir yüzey sıcaklık dağılımına sahip olan 14 kanatçıklı yapının en optimize imal edilebilir ürün olduğuna karar verilmiş ve bu gövde yapısının imalatı gerçekleştirilmiştir.

\section{SONUÇLAR VE DEĞERLENDİRME}

Dünyada sürekli artış eğilimi gösteren enerji ihtiyacından dolayı atık 1sıdan enerji elde edilmesi üzerine çalışmalar da artmaktadır. Harcanan enerjinin büyük bir bölümünü egzoz gazıyla atmosfere atan içten yanmalı motorların atık 1sısından enerji elde edilmesi de bu hususta dikkat çeken çalışmaları oluşturmaktadır. Gelişen teknolojinin bir ürünü olan ve yüzeyleri arasındaki sıcaklık farkıyla elektrik üreten TEM'ler ise bu atık ısılardan elektrik elde etmekte büyük işleve sahiptir.

Bu çalışmada, egzoz atık ısısından TEJ ile elektrik enerjisi elde etmek amacıyla 1sı eşanjörü tasarlanmıştır. Bu eşanjörün TEM ile temas ettiği yüzeylerde en iyi sıcaklık dağılımını elde etmek için eşanjör gövdesi içerisine 12, 14, 16 ve 18 kanatçıklar eklenmiştir. Kanatçıklı yapıdaki bu eşanjör gövdeleri ayrı ayrı ANSYS Fluent de analiz edilerek 1sıl dağılım grafikleri kıyaslanmıştır. Yapılan analizlerde gövdeye egzoz giriş sıcaklığı $250{ }^{\circ} \mathrm{C}$ olarak kabul edilmiştir. Analizlere göre farklı kanatçık yapılarına sahip eşanjör yüzeylerindeki maksimum sıcaklık değerlerinin $223-229{ }^{\circ} \mathrm{C}$ arasında değişim gösterdiği gözlemlenmiştir.

Analizin ısıl dağılım sonuçlarına göre maksimum sıcaklık dağılımına sahip gövde yapısının 1sı transferini arttırdığından dolayı kanatçık yapısı en fazla olan 18 kanatçıklı yapı olduğu görülmektedir. Ancak bu çalışmada yüzey alanının kanatçık sayısını çok arttırarak genişletilmesinin sonucu olarak motorun çalışmasını ve performansını etkileyen egzoz gazının geçişine engel olmaması ele alınmıştır. Tasarıma benzerliğini arttırmak için imalatının kolay olması da göz önüne alındığında, deneysel çalışma düzeneği için 14 kanatçıklı eşanjör gövdesinin daha uygun olduğu sonucuna varılmış ve bu yapının imalatı gerçekleştirilmiştir. Daha sonra egzoz atık 1sısından TEM ile elektrik üretmek için soğutucu ekipmanlar ve egzoz bağlantısı eklenerek deneysel çalışma düzeneği hazırlanmıştır. 


\section{Kaynaklar}

[1] BP Statistical Review of World Energy. June 2017.

[2] Enerji. Temiz Enerji Vakfi. MEB yayınları 3668. İstanbul, 2002.

[3] Wei He, Gan Zhang, Xingxing Zhang, Jie Ji, Guiqiang Li, Xudong Zhao. Recent development and application of thermoelectric generator and cooler. Applied Energy 143 (2015) 1-25.

[4] Song Lan, Zhijia Yang, Rui Chen, Richard Stobart. A dynamic model for thermoelectric generator applied to vehicle waste heat recovery. Applied Energy 210 (2018) 327-338.

[5] Srithar Rajoo, Alessandro Romagnoli, Ricardo MartinezBotas, Apostolos Pesiridis, Colin Copeland and A.M.I.Bin Mamat. Automotive exhaust power and waste heat recovery technologies. Automotive Exhaust Waste Heat Recovery Technologies Chapter 9, 2014.

[6] B. Orr, A. Akbarzadeh, P. Lappas. An exhaust heat recovery system utilising thermoelectric generators and heat pipes. Applied Thermal Engineering 126 (2017) 11851190 .

[7] Changxin Liu, Xinxiang Pan, Xiaofeng Zheng, Yuying Yan, Weizhong. Li. An experimental study of a novel prototype for two-stage thermoelectric generator from vehicle exhaust. Journal of the Energy Institute 89 (2016) $271 \mathrm{e} 281$.

[8] C.Q. Su, W.S. Wang, X. Liu, Y.D. Deng. Simulation and experimental study on thermal optimization of the heat exchanger for automotive exhaust-based thermoelectric generators. Case Studies in Thermal Engineering 4 (2014) 85-91.

[9] HoSung Lee. Thermal Design Heat Sinks, Thermoelectrics, Heat Pipes, Compact Heat, Exchangers and Solar Cells. John Wiley\&Sons, Inc. Hoboken, New Jersey, 2010.

[10] İlker TEMIZZR. Termoelektrik jeneratörü kullanılan taşıtlarda egzoz gazlarından elektrik üretilmesi. Makine Eğitimi Anabilim Dalı, Doktora Tezi, 2014.

[11] ChihWu. Analysis of waste-heat thermoelectric power generators. Applied Thermal Engineering Volume 16, Issue 1, January 1996, Pages 63-69.

[12] Raşit AHISKA, Hayati MAMUR ve Metin ULİŞ. Termoelektrik modülün jeneratör olarak modellenmesi ve deneysel çalışması. Gazi Üniv. Müh. Mim. Fak. Der. Cilt 26, No 4, 889-896, 2011.

[13] Sadık KAKAÇ. Isı Transferine Giriş - I Isı İletimi. Tıp\&Teknik yayıncılık. 6. Baskı, Ekim 1998. 


\section{Kisaltmalar}

TEJ: Termoelektrik jeneratör

TEM: Termoelektrik modül

mtep: Milyon ton eşdeğer petrol

CFD: Computational fluid dynamics 